\title{
Pengaruh pemberian pakan buatan menggunakan limbah kepala udang terhadap laju pertumbuhan dan kelangsungan hidup benih Ikan Gurame (Osphronemus gouramy)
}

\author{
The effect of preparation of fish feed using head-shrimp waste on the growth rate \\ and survival rate of Gurame Fish seed (Osphronemus gouramy) \\ ${ }^{1}$ Juliana, ${ }^{2}$ Yuniarti Koniyo, dan ${ }^{3}$ Citra Panigoro \\ ${ }_{, 2}^{1,2}$ udidaya Perairan, FPIK Universitas Negeri Gorontalo \\ ${ }^{3}$ Manajemen Sumberdaya Perairan, FPIK Universitas Negeri Gorontalo \\ Email: juliana@ung.ac.id
}

\begin{abstract}
ABSTRAK
Pakan dalam kegiatan budidaya ikan memerlukan biaya yang paling tinggi dibandingkan dengan biaya produksi lainnya. Salah satu cara untuk menekan biaya produksi adalah dengan menggunakan sumber bahan baku pakan yang tersedia dalam jumlah yang banyak, memiliki nilai gizi tinggi dan harganya murah. Penelitian ini bertujuan untuk mengetahui pengaruh pemberian pakan buatan dengan menggunakan limbah kepala udang dengan dosis berbeda terhadap pertumbuhan dan kelangsungan hidup benih ikan Gurame (Osphronemus gouramy). Penelitian ini menggunakan metode eksperimen, dengan Rancangan Acak Lengkap (RAL) dan 4 perlakuan 3 ulangan. Hewan uji yang digunakan adalah benih ikan Gurame (Osphronemus gouramy) sebanyak 240 ekor dengan rata-rata panjang awal $3 \mathrm{~cm}$ dan berat awal 1.3 gram, dengan padat tebar 2 ekor/liter. Perlakuan yang digunakan dalam penelitian ini adalah dosis pakan berbeda yaitu (A) $5 \%$, (B) 10\%, (C) $15 \%$ dan (D) $20 \%$. Wadah penelitian yang digunakan berupa 12 buah akuarium dengan volume 16 liter dan dilengkapi dengan aerasi. Pengukuran panjang dan berat benih dilakukan seminggu sekali dan pemeliharaan benih ikan berlangsung selama 3 bulan. Analisa data menggunakan analisis sidik ragam (ANOVA) pada taraf kepercayaan 95\%. Berdasarkan hasil analisa sidik ragam menunjukkan bahwa pemberian pakan dengan dosis yang berbeda tidak berpengaruh terhadap pertumbuhan panjang (Fhit $0.38<$ Ftab 4.07) dan pertumbuhan berat (Fhit $0.01<$ Ftab 4.07) benih ikan Gurame (Osphronemus gouramy). Pemberian pakan dengan dosis yang berbeda juga tidak berpengaruh terhadap kelangsungan hidup benih ikan Gurame (Fhit 3.99 < Ftab 4.07)
\end{abstract}

Kata kunci : Kelangsungan Hidup, Limbah Kepala Udang, Osphronemus gouramy, Pakan, Pertumbuhan

\begin{abstract}
Feed in fish farming activities requires the highest cost compared to other production costs. One way to reduce the cost of production is to use the source of feed ingredients that are available in large quantities, have high nutritional value and the price is cheap. This study aims to determine the effect of artificial feeding using shrimp head waste with different doses on growth and survival of gouramy seed (Osphronemus gouramy). This study used experimental method, with Completely Randomized Design (RAL) and 4 treatment 3 replication. The test animal used is the gouramy seed (Osphronemus gouramy) of 240 with an average initial length of $3 \mathrm{~cm}$ and an initial weight of 1.3 grams, with a dense stocking of 2 tails liter ${ }^{-1}$. The treatments used in this study were
\end{abstract}


different feed dosages (A) 5\%, (B) 10\%, (C) $15 \%$ and (D) 20\%. Research container used in the form of 12 aquariums with volume 16 liters and equipped with aeration. Measurements of seed length and weight were done once a week and the maintenance of fish seeds lasted for 3 months. Data analysis using analysis of variance (ANOVA) at 95\% confidence level. Based on the results of the analysis of variance showed that feeding with different doses did not affect the long growth (Fhit $0.38<$ Ftab 4.07) and growth weight (Fhit 0.01 <Ftab 4.07) Gurame fish seed (Osphronemus gouramy). Feeding with different doses also did not affect the survival of Gurame fish seed (Fhit $3.99<$ Ftab 4.07).

Keywords: Survival Rate, Shrimp Head Waste, Osphronemus Gouramy, Feed, Growth Rate

\section{Pendahuluan}

Pakan merupakan salah satu aspek penting yang harus diperhatikan dalam kegiatan budidaya, sebab pakan merupakan sumber energi untuk menunjang pertumbuhan. Pakan yang baik adalah pakan yang sesuai dengan kebutuhan fisiologi dan spesies ikan yang dibudidayakan disamping mampu untuk memenuhi kebutuhan nutrisi ikan tersebut. Pemberian pakan dengan kualitas dan kuantitas yang baik dapat mengoptimalkan usaha budidaya ikan. Pakan harus tersedia dalam jumlah yang cukup, diberikan pada waktu yang tepat, dan mempunyai kandungan gizi yang dibutuhkan untuk pertumbuhan ikan (Kurniasih, $d k k ., 2014$ ).

Kandungan nutrisi yang utama pada pakan adalah kandungan protein. Protein merupakan sumber energy utama yang dapat diperoleh oleh komoditas budidaya melalui pakan yang diberikan. Bahan baku pembuatan pakan untuk memenuhi kebutuhan protein ikan yang dibudidayakan harus mengandung protein kasar lebih besar dari $19 \%$. Bahan baku pakan yang memiliki protein lebih rendah dari 19\% dapat digolongkan sebagai sumber energy. Kebutuhan protein pakan setiap jenis ikan berbeda-beda, tetapi kebutuhan protein pakan pada ikan umumnya berkisar anatar 2060\% sedangkan kebutuhan optimal protein berkisar antara 30-36\% (Dini, et al., 2015).

Biaya pakan komersil yang terlalu tinggi, menyebabkan perlunya dilakukan alternatif pakan buatan yang dapat dilakukan secara mandiri oleh pembudidaya sehingga dapat menjadi sumber usaha baru bagi masyarakat dan menurunkan biaya produksi pada usaha budidaya perikanan. Pembuatan pakan alternatif yang banyak dilakukan pada saat ini adalah pembuatan pakan dengan menggunakan bahan dasar lokal. Bahan dasar alternatif yang banyak digunakan dalam pembuatan pakan ikan lokal adalah tepung kepala udang, tepung jagung, dedak, ampas ketela dan ampas tahu.

Selain memiliki nutrisi yang cukup, bahan baku juga harus mudah diperoleh dan memiliki harga yang murah. Limbah yang berasal dari nabati dan hewani dapat dijadikan bahan baku alternatif dalam pembuatan pakan. Limbah nabati dan hewani pada umumnya memiliki kandungan nutrisi yang cukup tinggi, termasuk kandungan protein yang dapat menggantikan sumber protein pada pakan komersil. Limbah nabati yang banyak dijumpai antara lain ampas tahu, bungkil kelapa, ampas kedelai. Sedangkan limbah hewani antara lain limbah kepala udang, limbah ikan ataupun ikan rucah yang telah mengalami penurunan mutu. Limbah ini berasal dari limbah rumah tangga maupun industri yang tidak termanfaatkan secara optimal dan dianggap tidak memiliki nilai ekonomi. Limbah kepala udang merupakan salah satu limbah hasil produksi dari pabrik udang beku tanpa kepala yang dapat dimanfaatkan sebagai bahan 
baku pembuatan pakan ikan. Limbah kepala udang jumlahnya cukup tinggi dan mengandung nilai nutrisi yang cukup baik. Limbah kepala udang mengandung protein sekitar 35-40\% protein (Mathius I.W., dan A.P.Sinurat, 2001). Selain Pakan, spesies ikan yang dibudidayakan juga merupakan salah satu faktor penting yang perlu diperhatikakan, karena akan berpengaruh terhadap pendapatan pembudidaya. Ikan yang dibudidayakan harus digemari masyarakat dan memiliki nilai ekonomi yang cukup baik. Ikan Gurame (Osphronemus gouramy) adalah satu ikan yang cukup digemari untuk dikonsumsi dan mempunyai nilai ekonomi yaitu ikan Gurame serta merupakan ikan asli perairan Indonesia. Masyarakat Indonesia sudah lama mengenal Gurame, rasa dagingnya yang gurih dan lezat sangat digemari masyarakat Ikan Gurame (Osphronemus gouramy) banyak dikembangkan oleh para petani, hal ini dikarenakan permintaan pasar yang cukup tinggi dan pemeliharaannya yang relatif mudah.

Pakan dan jenis organisme budidaya merupakan faktor penting dalam keberhasilan kegiatan budidaya perikanan. Berdasarkan uraian diatas, Limbah kepala udang merupakan salah satu bahan baku alternatif yang dapat digunakan dalam pembuatan pakan ikan, selain itu ikan Gurame merupakan salah satu spesies ikan budidaya yang memiliki nilai ekonomis. Hal tersebut yang melatarbelakangi dilakukannya penelitian ini. Penelitian ini bertujuan untuk mengetahui pengaruh pemberian pakan buatan menggunakan limbah kepala udang terhadap pertumbuhan dan kelangsungan hidup benih ikan Gurame (Osphronemus gouramy) dan mengetahui dosis pakan yang memberikan pertumbuhan dan kelangsungan hidup tertinggi pada benih ikan Gurame (Osphronemus gouramy). Sedangkan manfaat penelitian yaitu memberikan informasi bagi masyarakat khususnya pembudidaya ikan mengenai pertumbuhan dan kelangsungan hidup benih ikan Gurame yang diberikan pakan buatan berbahan baku limbah kepala udang.

\section{Metodologi penelitian}

Penelitian ini berlangsung di Laboratorium Program Studi Budidaya Perairan Fakultas Perikanan dan Kelautan, Universitas Negeri Gorontalo. Penelitian berlangsung selama tiga bulan yaitu pada bulan Mei - Juli 2017. Pakan buatan yang digunakan dalam perlakuan di analisa pada Laboratorium Perindustrian Manado.

Penelitian menggunakan rancangan acak lengkap (RAL) dengan empat perlakuan. Perlakuan yang digunakan adalah perbedaan dosis pemberian pakan buatan menggunakan limbah kepala udang dan dilakukan tiga kali ulangan untuk setiap perlakuan. Perlakuan yang digunakan terdiri dari perlakuan A adalah pemberian pakan buatan limbah kepala udang sebanyak 5\%, perlakuan B adalah pemberian pakan buatan limbah kepala udang sebanyak $10 \%$, perlakuan $\mathrm{C}$ adalah pemberian pakan buatan limbah kepala udang sebanyak $15 \%$, dan perlakuan D adalah pemberian pakan buatan limbah kepala udang sebanyak $20 \%$.

Hewan uji yang digunakan adalah benih ikan Gurame yang mempunyai ukuran panjang sebesar $\pm 3 \mathrm{~cm}$ dan berat 1.3 gr. Benih ikan Gurame yang digunakan sebanyak 240 ekor dengan kepadatan 2 ekor liter ${ }^{-1}$. Pakan uji yang digunakan adalah pakan buatan menggunakan bahan baku limbah kepala udang, tapioka, vitamin dan mineral. Kandungan protein berdasarkan hasil uji pada laboratorium perindustrian Manado adalah 29.76\%. Media pemeliharaan menggunakan air tawar yang sudah difilter dan diaerasi selama satu malam. Alat yang digunakan selama penelitian adalah akuarium bervolume 16 liter, aerator untuk suplai oksigen, dan alat kualitas air berupa $\mathrm{pH}$ meter 
untuk mengukur $\mathrm{pH}$, DO meter untuk mengetahui oksigen terlarut dan thermometer untuk mengetahui suhu. Pengambilan data pertumbuhan, kelangsungan hidup dan kualitas media pemeliharaan dilakukan seminggu sekali. Data pertumbuhan berupa pertumbuhan panjang mutlak dan berat mutlak, dedangkan parameter kualitas air yang diukur selama penelitian adalah Oksigen terlarut (DO), $\mathrm{pH}$ dan suhu. Penyiponan media pemeliharaan dilakukan setiap hari pada pagi hari dengan pergantian air sebanyak $25 \%$, sedangkan pergantian air sebanyak $75 \%$ dilakukan setiap seminggu sekali yaitu pada saat pengukuran benih. Penyiponan dan pergantian air dilakukan untuk menjaga kualitas media pemeliharaan. Frekuensi pemberian pakan selama penelitian dilakukan sebanyak 2 kali sehari, yaitu pada pagi dan sore hari, sebelum pakan di berikan terlebih dahulu ditimbang sesuai dengan dosis yang sudah ditentukan yaitu 5\%, 10\%, 15\% dan $20 \%$.

Variabel yang diukur pada penelitian ini adalah pertumbuhan panjang mutlak, pertumbuhan berat mutlak dan kelangsungan hidup. Rumus untuk variabel-variabel tersebut adalah:

\subsection{Pertumbuhan mutlak}

Pertumbuhan mutlak pada penelitian terdiri dari pertumbuhan panjang mutlak dan pertumbuhan berat mutlak. Perhitungan pertumbuhan panjang mutlak menurut Cholik et al., (2005) :

\section{Keterangan :}

$$
L=\mathbf{L t}-\mathbf{L o}
$$

$L_{t}=$ Panjang akhir penelitian waktu minggu ke $-\mathrm{t}$

$L_{o}=$ Panjang awal

Perhitungan pertumbuhan berat mutlak menurut Cholik et al., (2005) :

$$
\boldsymbol{W}=\mathbf{W t}-\mathbf{W o}
$$

Keterangan :

$W_{t}=$ Berat akhir penelitian waktu minggu ke $-\mathrm{t}$

$W_{o}=$ Berat awal

\subsection{Kelangsungan Hidup (Survival Rate)}

Kelangsungan hidup atau survival rate (SR) adalah persentase jumlah biota yang hidup pada akhir waktu tertentu, rumus yang digunakan menurut Cholik et al., (2005) adalah :

$$
S R=\frac{\mathrm{Nt}}{\mathrm{No}} \times 100 \%
$$

\section{Keterangan:}

SR : Kelangsungan Hidup

$\mathrm{Nt}=$ Jumlah benih akhir penelitian

No $=$ Jumlah benih awal penelitian 


\subsection{Analisis data}

Data yang diperoleh terdiri dari data pertumbuhan dan kelangsungan hidup benih ikan Gurame. Hasil penelitian tersebut akan dianalisa dengan menggunakan analisi sidik ragam (ANOVA) pada taraf kepercayaan 95\%. Hal ini dilakukan untuk mengetahui pengaruh pemberian pakan buatan menggunakan limbah kepala udang terhadap pertumbuhan dan kelangsungan hidup benih ikan Gurame (Osphronemus gouramy).

\section{Hasil dan Pembahasan}

\subsection{Pertumbuhan mutlak benih ikan Gurame (Osphronemus gouramy)}

Pertumbuhan panjang dan berat mutlak benih ikan Gurame (Osprhonemus gouramy) selama 3 bulan dengan menggunakan empat perlakuan dosis yang berbeda yakni perlakuan A $(5 \%)$, perlakuan B $(10 \%)$, perlakuan C $(15 \%)$ dan perlakuan D (20\%). Hasil pengukuran panjang mutlak dan berat mutlak benih ikan Gurame selama penelitian dapat dilihatn pada Tabel 1.

Tabel 1. Pertumbuhan Panjang dan Berat Mutlak Benih Ikan Gurame (Osphronemus gouramy).

\begin{tabular}{ccc}
\hline Perlakuan & \multicolumn{2}{c}{ Pertumbuhan Mutlak } \\
\cline { 2 - 3 } & Panjang (cm) & Berat (gram) \\
\hline A (Dosis 5\%) & 3.24 & 2.29 \\
B (Dosis 10\%) & 3.26 & 2.31 \\
C (Dosis 15\%) & 3.27 & 2.33 \\
D (Dosis 20\%) & 3.32 & 2.44 \\
\hline
\end{tabular}

Berdasarkan hasil perhitungan panjang mutlak dan berat mutlak benih ikan Gurame pada setiap perlakuan dengan pemberian dosis pakan yang berbeda menunjukkan bahwa pada pertumbuhan panjang dan berat rata-rata setiap individu memiliki panjang dan berat yang tidak terlalu berbeda. Hasil pengukuran pertumbuhan panjang mutlak benih ikan Gurame untuk perlakuan A, perlakuan B, perlakuan $\mathrm{C}$ dan Perlakuan D adalah $3.24 \mathrm{~cm}-3.32 \mathrm{~cm}$. Pertumbuhan panjang mutlak tertinggi diperoleh pada perlakuan D yaitu pemberian dosis pakan buatan sebanyak 20\%, sedangkan terendah diperoleh pada perlakuan A yaitu pemberian dosis pakan buatan sebanyak $5 \%$. Hasil pengukuran terhadap pertumbuhan berat mutlak benih ikan Gurame pada setiap perlakuan yaitu pada perlakuan A sebesar 2.29 gr, perlakuan B sebesar 2.31 gr, perlakuan C sebesar 2.33 gr, dan perlakuan D sebesar 2.44 gr. Berdasarkan pertumbuhan berat mutlak benih ikan Gurame (Osphronemus gouramy) menunjukkan bahwa pertumbuhan berat mutlak tertinggi diperoleh pada perlakuan $\mathrm{D}$ dengan pemberian dosis pakan buatan sebanyak $20 \%$ dan pertumbuhan berat mutlak terendah pada perlakuan A dengan pemberian dosis pakan buatan sebanyak 5\%.

Hasil penelitian terhadap pertumbuhan berat mutlak dan panjang mutlak benih ikan Gurame (Osphronemus gouramy) yang diberi pakan buatan dengan dosis berbeda dilanjutkan dengan analisis sidik ragam (ANOVA) untuk mengetahui pengaruh pemberian pakan dengan dosis berbeda terhadap pertumbuhan benih ikan Gurame (Osphronemus gouramy). Hasil pengukuran panjang mutlak dan berat mutlak benih ikan Gurame (Osphronemus gouramy) menggunakan anilisis sidik ragam terdapat pada Tabel 2 dan Tabel 3. 
Tabel 2. Hasil Analisis Sidik Ragam Pertumbuhan Panjang Mutlak

\begin{tabular}{lccccc}
\hline $\begin{array}{c}\text { Sumber } \\
\text { Keragaman }\end{array}$ & $\begin{array}{c}\text { Derajat } \\
\text { Bebas }\end{array}$ & $\begin{array}{c}\text { Jumlah } \\
\text { Kuadrat }\end{array}$ & $\begin{array}{c}\text { Kuadrat } \\
\text { Tengah }\end{array}$ & $\mathbf{F}_{\text {Hitung }}$ & $\begin{array}{c}\mathbf{F}_{\text {Tabel }} \\
\mathbf{5} \%\end{array}$ \\
\hline Perlakuan & 3 & 0.000025 & 0.000008 & 0.3773 & 4.07 \\
Galat & 8 & 0.001766 & 0.000220 & & \\
Total & 11 & 0.001791 & & & \\
\hline
\end{tabular}

Tabel 3. Hasil Analisis Sidik Ragam Pertumbuhan Berat Mutlak

\begin{tabular}{lccccc}
\hline $\begin{array}{c}\text { Sumber } \\
\text { Keragaman }\end{array}$ & $\begin{array}{c}\text { Derajat } \\
\text { bebas }\end{array}$ & $\begin{array}{c}\text { Jumlah } \\
\text { Kuadrat }\end{array}$ & $\begin{array}{c}\text { Kuadrat } \\
\text { Tengah }\end{array}$ & $\mathbf{F}_{\text {Hitung }}$ & $\mathbf{F}_{\text {Tabel }}$ \\
\hline Perlakuan & 3 & 0.0000006 & 0.0000001 & 0.167 & $5 \%$ \\
Galat & 8 & 0.000008 & 0.000001 & & \\
Total & 11 & 0.000008 & & & \\
\hline
\end{tabular}

Berdasarkan hasil analisis di atas pertumbuhan panjang dan berat mutlak benih ikan Gurame (Osprhonemus Gouramy) menunjukkan bahwa pemberian dosis pakan yang berbeda tidak memberikan pengaruh $\left(\mathrm{F}_{\text {hit }}<\mathrm{F}_{\text {tabel }}\right)$ terhadap pertumbuhan panjang mutlak dan berat mutlak benih ikan Gurame (Osprhonemus Gouramy). Hasil analisis sidik ragam terhadap pertumbuhan panjang mutlak benih ikan Gurame yaitu (Fhit < Ftab) yaitu $0.3773>4.07$, sehingga hasil tersebut menunjukkan pertumbuhan panjang mutlak tidak dipengaruhi oleh pemberian dosis pakan buatan yang berbeda. Hasil analisis sidik ragam terhadap pertumbuhan berat mutlak memberikan juga hasil yang menyatakan bahwa pemberian pakan buatan dengan dosis berbeda tidak berpengaruh terhadap pertumbuhan berat mutlak (Fhit < Ftab : $0.167>4.07$ ) benih ikan Gurame (Osprhonemus Gouramy).

Pada penelitian ini hasil uji proksimat pada pakan buatan menggunakan limbah kepala udang mengandung protein sebesar 29.78\%. Menurut (Sahwan, 2002) kebutuhan protein untuk benih ikan Gurame ukuran $3-4 \mathrm{~cm}$ yaitu 32\%, sehingga kandungan protein pada pakan yang diuji pada penelitian ini cukup untuk memenuhi kebutuhan protein benih ikan Gurame (Osprhonemus Gouramy). Salah satu nutrient penting yang dibutuhkan ikan adalah protein, karena protein merupakan zat pakan yang sangat diperlukan bagi pertumbuhan. Pemanfaatan protein bagi pertumbuhan ikan dipengaruhi oleh beberapa faktor, antara lain ukuran ikan, umur ikan, kualitas protein pakan, kandungan energi pakan, suhu air dan frekuensi pemberian pakan. Protein yang terkandung pada tepung kepala udang sebagai bahan baku pada pakan buatan berdasarkan hasil uji proksimat yaitu mengandung protein sebanyak $32.17 \%$. Menurut Halver dan Ronald (2002) kandungan protein yang cukup untuk memenuhi kebutuhan ikan adalah 35\% - 45\%. Sedangkan Subekti, et al (2011) menyatakan bahwa kandungan protein pakan dipengaruhi oleh bahan baku yang digunakan dalam pembuatan pakan. Bahan baku yang digunakan dalam pembuatan pakan ikan sebaiknya mengandung protein paling rendah sebesar $35 \%$.

Pemberian pakan yang berkualitas, baik pakan buatan maupun hijauan pada tahapan produksi ikan Gurame merupakan satu hal yang penting. Menurut (Halver dan 


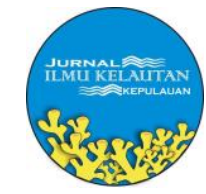

Ronald, 2002) bahwa pakan ikan mempunyai peranan penting bagi pertumbuhan dan tingkat kelangsungan hidup ikan. Anggraeni dan Nurlita (2013), menyatakan bahwa jenis pakan yang berbeda akan berpengaruh terhadap pertumbuhan dan kelangsungan hidup benih ikan yang dibudidayakan.

\subsection{Kelangsungan hidup benih ikan Gurame (Osphronemus gouramy)}

Kelangsungan hidup atau survival rate benih ikan Gurame (Osphronemus gouramy) adalah persentase jumlah benih ikan yang hidup pada akhir waktu penelitian, sedangkan mortalitas adalah persentase jumlah benih ikan Gurame yang mati pada akhir penelitian. Mortalitas yang terjadi pada suatu populasi organisme akan menyebabkan berkurangnya jumlah individu populasi tersebut. Kelangsungan hidup atau survival rate benih ikan Gurame (Osphronemus gouramy) pada akhir penelitian dapat dilihat pada Gambar 1.

Perhitungan nilai kelangsungan hidup benih ikan Gurame diperoleh dari jumlah benih yang hidup pada akhir penelitian dibagi dengan jumlah benih pada awal penelitian, lalu dikali dengan $100 \%$. Hasil perhitungan kelansungan hidup ikan Gurame (Osphronemus gouramy) menunjukan bahwa presentase kelangsungan hidup benih ikan Gurame (Osphronemus gouramy) yang tertinggi adalah terdapat pada perlakuan D yaitu pemberian dosis pakan buatan sebanyak $20 \%$ dan nilai kelangsungan hidup benih ikan yang diperoleh adalah sebesar $76.70 \%$. Sedangkan kelangsungan hidup terendah diperoleh pada perlakuan A yaitu pemberian dosis pakan buatan sebanyak 5\% dan nilai kelangsungan hidup benih ikan sebesar 53.3\%.

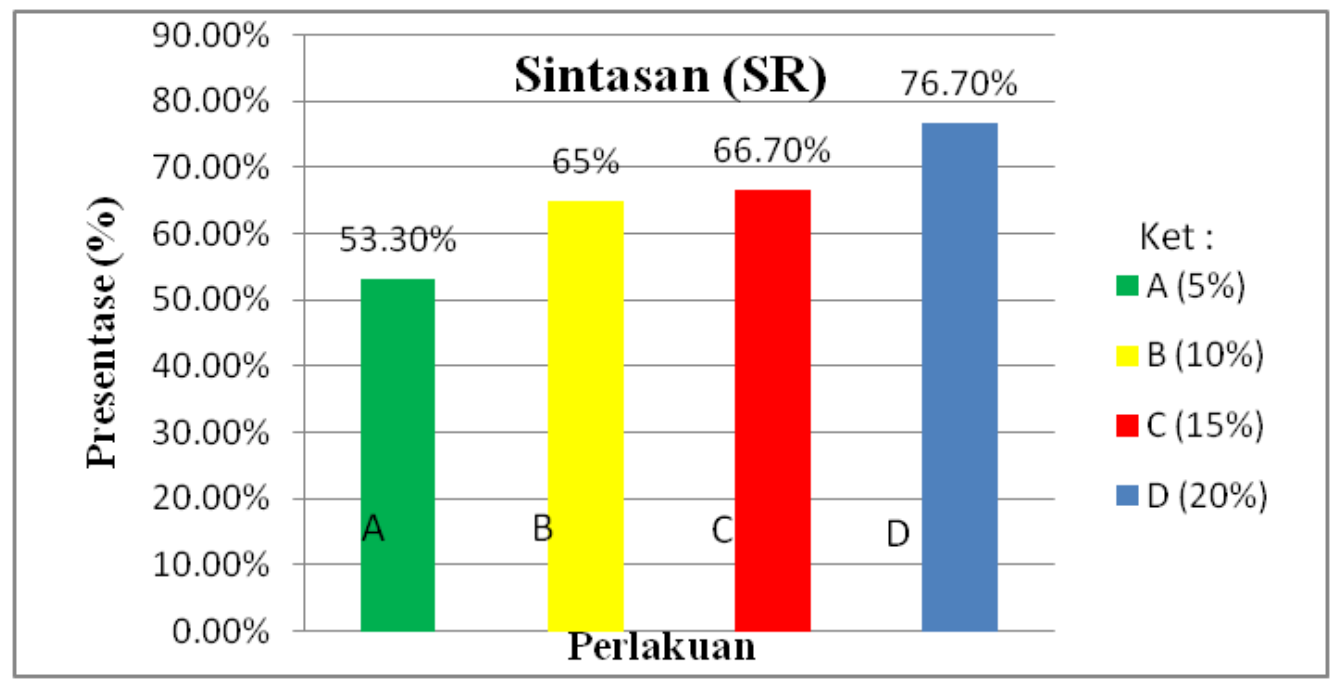

Gambar 1. Kelangsungan Hidup Benih Ikan Gurame (Osphronemus gouramy)

Tingginya tingkat kelangsungan hidup benih ikan Gurame diduga karena terpenuhinya kebutuhan pakan untuk kelangsungan hidup dan kondisi lingkungan pemeliharaan yang sesuai sehingga kondisi stress pada ikan selama pemeliharaan dapat terhindarkan. Selain itu juga didukung oleh faktor kualitas air, dimana tiap perlakuan selama penelitian masih berada pada kisaran yang normal untuk kelangsungan hidup dan proses pertumbuhan ikan Gurame, kelangsungan hidup sangat ditentukan oleh ketersediaan pakan dan kualitas air.

Berdasarkan (Kordi, 2009) bahwa rendahnya kelansungan hidup suatu biota budidaya dipengaruhi beberapa faktor salah satunya adalah nutrisi pakan yang tidak 
sesuai. Pakan yang memiliki kandungan nutrisi yang tidak memenuhi kebutuhan hidup benih ikan diduga dapat mengakibatkan kondisi fisiologi benih ikan menurun. Kandungan nutrisi pakan yang rendah akan memperlambat pertumbuhan dan berpengaruh terhadap kelangsungan hidup biota budidaya. Hasil pengukuran terhadap kelangsungan hidup benih ikan Gurame dilanjutkan dengan analisis sidik ragam. Hasil perhitungan analisis sidik ragam untuk kelangsungan hidup benih ikan Gurame dapat dilihat pada Tabel 4.

Tabel 4. Analisis Sidik Ragam Kelangsungan Hidup Benih Ikan Gurame

\begin{tabular}{lccccc}
\hline $\begin{array}{c}\text { Sumber } \\
\text { Keragaman }\end{array}$ & $\begin{array}{c}\text { Derajat } \\
\text { Bebas }\end{array}$ & $\begin{array}{c}\text { Jumlah } \\
\text { Kuadrat }\end{array}$ & $\begin{array}{c}\text { Kuadrat } \\
\text { Tengah }\end{array}$ & $\begin{array}{c}\text { F } \\
\text { Hitung }\end{array}$ & F Tabel \\
\hline Perlakuan & 3 & 0.08229 & 0.02743 & 3.99 & 4.07 \\
Galat & 8 & 0.055 & 0.00687 & & \\
Total & 11 & 0.13729 & & & \\
\hline
\end{tabular}

Berdasarkan hasil analisis sidik ragam benih ikan Gurame (Osprhonemus Gouramy) menunjukkan bahwa pemberian dosis pakan yang berbeda tidak memberikan pengaruh nyata $\left(\mathrm{F}_{\text {hit }}<\mathrm{F}_{\text {tabel }}\right)$ terhadap kelansungan hidup benih ikan Gurame (Osprhonemus Gouramy).

\subsection{Kualitas air}

Hasil pengukuran kualitas air selama pemeliharaan benih ikan Gurame (Osphronemus Gouramy) menunjukkan bahwa kisaran yang diperoleh masih berada pada batas yang baik bagi kehidupan benih. Hasil pengukuran parameter kualitas air selama penelitian dapat dilihat pada Tabel 5.

Tabel 5. Parameter kualitas Air Selama Penelitian

\begin{tabular}{cccc} 
& \multicolumn{3}{c}{ PARAMETER } \\
\cline { 2 - 4 } & SUHU $^{\mathbf{0}} \mathbf{C}$ & $\mathbf{p H}$ & $\mathbf{D O}\left(\mathbf{~ m g l}^{\mathbf{1}}\right)$ \\
\hline $\mathrm{A}$ & 27.32 & 7.07 & 5.08 \\
$\mathrm{~B}$ & 27.28 & 7.09 & 5.07 \\
$\mathrm{C}$ & 27.27 & 7.08 & 5.08 \\
$\mathrm{D}$ & 27.24 & 7.09 & 5.08 \\
\hline
\end{tabular}

Pengukuran parameter kualitas air pada penelitian ini dilakukan sekali dalam setiap minggu dengan menggunakan alat ukur Monitor Water Quality. Pengukuran dilakukan pada sore hari. Pengamatan suhu selama penelitian menunjukan kisaran antara $26-27{ }^{\circ} \mathrm{C}$ hal ini sesuai dengan pendapat (Herianti dan Isnani, 2005) bahwa suhu optimal pada kisaran $24-28{ }^{\circ} \mathrm{C}$ dapat mendukung pertumbuhan benih Gurame. Kenaikan suhu dalam batas-batas yang masih dapat ditoleransi akan menyebabkan laju metabolisme meningkat sehingga kebutuhan pakan untuk pemeliharaan tubuh bertambah dan lebih aktif mengambil pakannya. 
Hasil pengukuran $\mathrm{pH}$ air selama penelitian berkisar 6 - 7, berdasarkan data tersebut dapat dikatakan $\mathrm{pH}$ air selama penelitian adalah $\mathrm{pH}$ optimal untuk menunjang pertumbuhan dan kelansungan hidup benih ikan Gurame. Menurut Indra (2013) suhu dan $\mathrm{pH}$ merupakan faktor pembatas yang mempengaruhi dan menentukan jumlah konsumsi pakan, kecepatan reaksi laju metabolisme. Jika nilai $\mathrm{pH}$ air rendah dapat menyebabkan pengumpalan lender pada insang dan ikan akan mati lemas sehingga makanan yang dikonsumsi lebih banyak dimanfaatkan sebagai energy untuk mempertahankan tubuh daripada untuk pertumbuhan (Indra, 2013). Kandungan oksigen terlarut merupakan salah satu faktor paling penting dalam system perairan dan mutlak diperlukan untuk respirasi atau pernafasan. Secara umum hasil pengukuran kadar oksigen terlarut selama penelitian masih dalam kondisi yang aman untuk pertumbuhan ikan yaitu sekitar $5 \mathrm{mgl}^{-1}$.

\section{Kesimpulan}

Berdasarkan hasil penelitian dan pembahasan yang telah diuraikan sebelumnya, maka ada beberapa kesimpulan yang dapat diberikan yaitu :

1. Pemberian pakan buatan dengan menggunakan bahan baku limbah kepala udang dengan dosis berbeda tidak memberikan pengaruh terhadap pertumbuhan panjang mutlak (Fhit $0.3773<$ Ftab 4.07) dan berat mutlak (Fhit $0.1666<$ Ftab 4.07) benih ikan Gurame (Osphronemus Gouramy).

2. Pertumbuhan panjang mutlak dan berat mutlak tertinggi diperoleh pada perlakuan D yaitu pemberian pakan buatan dengan dosis $20 \%$, nilai pertumbuhan panjang mutlak yang diperoleh adalah $3.32 \mathrm{~cm}$ dan pertumbuhan berat mutlak adalah $2.44 \mathrm{gr}$. Sedangkan pertumbuhan panjang mutlak dan berat mutlak terendah diperoleh pada perlakuan A yaitu pemberian dosis pakan buatan sebanyak 5\% dengan nilai pertumbuhan panjang mutlak sebesar $3.24 \mathrm{~cm}$ dan pertumbuhan berat mutlak adalah 2.29 gr.

3. Pemberian pakan buatan menggunakan bahan baku limbah kepala udang dengan dosis berbeda tidak memberikan pengaruh terhadap kelangsungan hidup (Fhit 3.990 $<$ Ftab 4.07) benih ikan Gurame (Osphronemus Gouramy).

4. Kelangsungan hidup benih ikan tertinggi diperoleh pada perlakuan D yaitu pemberian pakan buatan dengan dosis $20 \%$, nilai kelangsungan hidup yang diperoleh adalah $76.70 \%$. Sedangkan kelangsungan hidup terendah diperoleh pada perlakuan A yaitu pemberian dosis pakan buatan sebanyak 5\% dengan nilai kelangsungan hidup benih ikan adalah $53.30 \%$

\section{Daftar Pustaka}

Anggraeni Novita Mardhia dan Nurlita Abdulgani, 2013. Pengaruh Pemberian Pakan Alami dan Pakan Buatan Terhadap Pertumbuhan Ikan Betutu (Oxyeleotris marmorata) pada Skala Laboratorium. Jurnal Sains dan Seni Pomits Vol.2, No.1

Arief. M.P, 2009. Agribisnis Ikan Gurame. CV.Pustaka Grafika Bandung

Arief Muhammad, Irmaya Triasih, dan Widya Paramita Lokapirnasari. 2009. Pengaruh Pemberian Pakan Alami terhadap Pertumbuhan Benih IKan Betutu (Oxyeleotris marmorata Bleeker). Jurnal Ilmiah Perikanan dan Kelautan Vol. 1 No.1.

Cholik, F., Ateng G.J., R. P. Purnomo dan Ahmad, Z. 2005. Akuakultur Tumpuan Harapan Masa Depan. Masyarakat Perikanan Nusantara dan Taman Akuarium Air Tawar. 
Halver, E. John and Ronald W. Wardy (Ed). 2002. Fish Nutrition. 3 Edition. Academic press. Bandung. $822 \mathrm{p}$.

Herianti dan Isnani. 2005. Rekayasa Lingkungan Untuk Memacu Perkembangan Ovarium Ikan Sidat (Anguilla bicolor). Balai Pengkajian Teknologi Pertanian Jawa Tengah. 18 hal.

Indra. R. 2013. Pengaruh Pemberian Pakan Alami Tubifex sp, Chironomus sp, Moina sp, dan Daphnia sp terhadap Pertumbuhan Benih Ikan Gurame Padang (Osphronemus gouramy Lac.). Skripsi, Fakultas Perikanan dan Ilmu Kelautan Universitas Padjajaran Bandung.

Kamil, M.T., R. Affandi, I. Mokognita \& D. Jusadi. 2000. Pengaruh Kadar Asam Lemak Omega 6 yang Berbeda Pada Kadar Asam Lemak Omega 3 Tetap Dalam Pakan Terhadap Pertumbuhan Ikan Sidat (Anguilla bicolor bicolor). Jurnal Central Kalimantan Fisheries Vol.1(1): 34-40.

Kordi, K. M.G.H. 2009. Budidaya Perairan. Citra Ditya Bakti. Bandung.

Lucas, W. 2015. Pertumbuhan dan kelansungan hidup larva Gurame (Osphronemus gouramy) dengan Pemberian beberapa Jenis Pakan. Skripsi, Program studi Budidaya Perairan, FPIK UNSRAT Manado.

Mashuri, Sumarjan, dan Abidin, Z., 2012. Pengaruh Jenis Pakan yang Berbeda terhadap Pertumbuhan Belut Sawah (Monopterus albus zuieuw). Jurnal Penelitian, Fakultas Pertanian Universitas Mataram.

Marzuqi M., dan Anjusary.D.N., 2013 Kecernaan Nutrien Pakan dengan Kadar Protein dan Lemak Berbeda Pada Juvenil Ikan Kerapu Pasir (Epinephelus Corallicola). Jurnal Ilmu dan Teknologi Kelautan Tropis. Fakultas Perikanan dan Ilmu Kelautan, Universitas Brawijaya, Malang

Prihartono RE, 2004. Permasalahan Gurami dan Solusinya. Penebar Swadaya, Jakarta

Rohy, G. B., Rahardja, B. S dan Agustono. 2014. Jumlah Total Bakteri dalam Saluran Pencernaan Ikan Gurami (Osphronemus gouramy) dengan Pemberian Beberapa Pakan Komersial Yang Berbeda. Fakultas Perikanan dan Kelautan Universitas Airlangga. Jurnal Ilmiah Perikanan dan Kelautan Vol. 6 No. 1.

Sahwan, M. F. 2002. Pakan Ikan dan Udang. Penebar Swadaya. Jakarta

Subekti Sri, Mutia Pawesti, dan Muh. Arief. 2011. Pengaruh Kombinasi Pakan Buatan dan Pakan Alami Cacing Sutera (Tubifex tubifex) dengan Persentase yang Berbeda terhadap Retensi Protein, Lemak dan Energi pada Ikan Sidat (Anguilla bicolor bicolor). Jurnal Kelautan, Vol. 4 No. 1. ISSN: 1907-9931

Sunarto dan Sabariah.,2009. Pemberian Pakan Buatan dengan Dosis Berbeda terhadap Pertumbuhan dan Konsumsi Pakan Benih Ikan Semah (Tor douronensis) dalam Upaya Domestikasi. Jurnal Aquakultur Indonesia. Fakultas Perikanan dan Ilmu Kelautan Universitas Muhammadiyah Pontianak.

Yandes, Z., A. Ridwan., M. Ing. 2003. Pengaruh Pemberian Selulosa dalam Pakan terhadap Kondisi Biologis Benih Ikan Gurami (Osphronemus gouramy). Fakultas Perikanan dan Ilmu Kelautan. Institut Pertanian Bogor. 